\title{
Novel Interleukin 2 (IL-2) Receptor Appears to Mediate IL-2-induced Activation of Natural Killer Cells
}

\author{
John H. Kehrl, ${ }^{*}$ Mitchell Dukovich, ${ }^{\ddagger}$ Gail Whalen, \\ ${ }^{*}$ Laboratory of Immunoregulation, National Institues of Allergy and Infectious Diseases, National Institutes of Health, Bethesda, \\ Maryland 20892; ${ }^{\ddagger}$ Howard Hughes Medical Institute, Duke University Medical Center, Durham, North Carolina 27710; and \\ ${ }^{\S}$ Division of Rheumatology, Immunology, and Allergy, Georgetown University School of Medicine, Washington, D. C.
}

\begin{abstract}
A novel IL-2 receptor, distinct from the Tac protein, has been identified on the surface of purified human natural killer (NK) cells by chemical cross-linking of ${ }^{125}$ I-IL-2. This protein is $\sim 70,000 \mathrm{D}$ in size (p70) and appears to be identical to the recently recognized second subunit of the human high affinity IL-2 receptor complex. Scatchard analysis of ${ }^{125}$ I-IL-2 binding to purified NK cells revealed $\sim 2,300$ p70 binding sites per cell with an apparent dissociation constant of $200 \mathrm{pM}$, a value intermediate between the previously recognized high and low affinity forms of the human IL-2 receptor. The monoclonal anti-Tac antibody did not inhibit the cross-linking of ${ }^{125}$ I-IL-2 to the p70 binding sites present on NK cells. Functionally, the addition of high concentrations of recombinant IL-2 to the enriched NK cells promoted a rapid augmentation of cytolytic activity and a more delayed increase in cellular proliferation. Anti-Tac effectively blocked the IL-2-induced proliferative response in these cells, but failed to alter the enhancement of cytotoxicity. Analysis of NK cytoplasmic RNA isolated at various time points after IL-2 stimulation revealed the rapid induction of c-myb and Tac gene expression that was also not inhibited by the anti-Tac antibody. These findings suggest that IL-2 binding to the $\mathbf{p 7 0}$ receptor constitutively expressed on the surface of NK cells may mediate both the development of increased cytolytic activity and rapid changes in gene expression. The activation of the Tac gene may in turn permit the formation of the high affinity IL-2 receptor complex (comprised of at least the Tac and $\mathbf{p 7 0}$ proteins) that appears to transduce the requisite signals involved in NK cell proliferation.
\end{abstract}

\section{Introduction}

Natural killer (NK) ${ }^{1}$ cells represent a heterogeneous population of lymphoid cells that exhibit cytotoxic activity against certain tumors and virally infected cells (reviewed in references 1 and 2). Characteristically, these cells are large and granular in morphology (3), react with the Leu 11 antibody $(4,5)$, and exhibit cytolytic function that is unrestricted by elements of the major histocompatibility complex $(1,2)$. The level of cyto-

Address all correspondence to Dr. J. H. Kehrl, National Institutes of Health, Bldg. 10, Rm. 11B-13, Bethesda, MD 20892.

Received for publication 15 May 1987 and in revised form $19 \mathrm{Au}$ gust 1987.

1. Abbreviations used in this paper: BRMP, Biological Response Modifier Program; NK, natural killer.

The Journal of Clinical Investigation, Inc.

Volume 81, January 1988, 200-205 toxic activity in peripheral blood lymphocytes and purified Leu $11^{+}$cell populations can be amplified by the addition of IL-2 (6-10). The IL-2-induced changes in NK cell cytotoxicity are (i) detectable within $4 \mathrm{~h}(9)$, (ii) dependent on protein but not DNA synthesis (9), (iii) dependent on relatively high concentrations of IL-2 (100-500 U/ml) (8-10), and (iv) independent of Tac antigen expression. Furthermore, purified Leu $11^{+}$ cell populations often express negligible levels of the Tac antigen, and Il-2-induced augmentation of their cytolytic activity is not inhibited by the anti-Tac antibody (8-11).

Recent ${ }^{125} \mathrm{I}$-IL-2 cross-linking studies with various human lymphoid cell lines and activated normal human $\mathrm{T}$ cells have led to the identification of a second human IL- 2 binding protein. This protein is $\sim 70,000-75,000 \mathrm{D}$ in size (p70), and appears able to noncovalently associate with the Tac antigen, forming a membrane complex that binds IL-2 with high affinity (12-16). Expression of the p70 protein in the absence of the Tac antigen has been detected on certain lymphoid cell lines, including MLA-144 T cells (13-16), SKW 6.4 B cells (16), and "natural killer like" YT cells $(15,16)$ as well as on various normal lymphoid populations, including resting $T$ cells (16, 17) and large granular lymphocytes (16).

In the present study, we have further characterized and quantitated the p70 IL-2 binding proteins present on human NK cells and investigated the potential functional role of these receptors in mediating IL-2-induced changes in NK cell cytotoxicity and proliferation.

\section{Methods}

Cell preparation. Human PBMC were obtained by leukopheresis of normal donors and separated from erthrocytes by centrifugation on Hypaque-Ficoll. The mononuclear cells were passed over nylon wool columns to deplete B cells and monocytes (18). The Leu $11^{+}$cells were further purified by negative selection utilizing an affinity rosetting technique (19). Briefly, the cells were incubated with a cocktail of monoclonal antibodies (anti-Leu 1 and anti-DR; Becton Dickinson \& Co., Sunnyvale, CA), (OKT3; Ortho Diagnostic Systems Inc., Raritan, $\mathrm{NJ}$ ), washed, and mixed with oxred blood cells previously coated with goat $\mathrm{F}\left(\mathrm{ab}^{\prime}\right)_{2}$ anti-mouse Ig (Boehringer Mannheim Biochemical, Indianapolis, IN) using a chromic chloride method. Cells forming rosettes with the ox-coated erythrocytes were eliminated from the suspensions by centrifugation on Hypaque-Ficoll cushions. These negatively selected NK cells were routinely 90-95\% Leu $11^{+}$and $<2 \%$ OKT3 positive, as determined by indirect immunofluorescent staining with the anti-Leu 11a (Becton Dickinson \& Co.) antibody.

Reagents. Recombinant IL-2 used in this study was kindly provided by the Cetus Corporation (Emeryville, CA). This material was $99 \%$ pure by SDS-PAGE analysis and contained $<0.01 \mathrm{ng}$ endotoxin per $10^{6} \mathrm{U}(20) .1$ pmol of IL-2 per liter (1 pM) is equivalent to 0.2 Biological Response Modifier Program (BRMP) reference units per $\mathrm{ml}$. The anti-Tac antibody used has been previously described (21, 22). The UPC10 monoclonal antibody, an $\mathrm{IgG}_{2 \mathrm{a}}$ myeloma protein of 
unknown specificity that is isotyped matched to the Tac protein, was purchased from Sigma Chemical Co. (St. Louis, MO).

Measurement of DNA synthesis. $1 \times 10^{5}$ cells were plated in $200 \mu \mathrm{l}$ of RPMI 1640 plus $10 \%$ FCS and $1 \mu \mathrm{Ci}$ of $\left[{ }^{3} \mathrm{H}\right]$ thymidine (New England Nuclear, Boston, MA) was added during the final $18 \mathrm{~h}$ of culture. The amount $\left[{ }^{3} \mathrm{H}\right]$ thymidine incorporated was measured by standard liquid scintillation techniques. To examine the effects of anti-Tac on IL-2-induced DNA synthesis, various concentrations of purified antiTac antibody were added at the initiation of cultures.

Cytotoxicity assay. NK activity was evaluated in a 4- $\mathrm{h}{ }^{51} \mathrm{Cr}$ release cytotoxicity assay using NK sensitive $\mathrm{K} 562$ cells as targets. Effector cells were incubated for $18 \mathrm{~h}$ in the presence of various concentrations of recombinant IL-2 in RPMI 1640 plus $10 \%$ FCS. In some experiments purified anti-Tac antibody was added. Target cells were labeled for $1 \mathrm{~h}$ with $300 \mu \mathrm{Ci}$ of ${ }^{51} \mathrm{Cr}$ (ICN Radiochemicals, Irvine, CA), washed three times, and resuspended in RPMI 1640 with $10 \%$ FCS. 10,000 labeled target cells $(100 \mu \mathrm{l})$ were mixed with varying numbers of effector cells $(100 \mu \mathrm{l})$ in 96-well V-bottom microtiter plates (Costar, Cambridge, MA). Spontaneous release of ${ }^{51} \mathrm{Cr}$ by target cells was determined by placing labeled target cells in microtiter wells in the absence of effector cells. Cultures were incubated in $5 \% \mathrm{CO}_{2}$ at $37^{\circ} \mathrm{C}$ in $100 \%$ humidity for $4 \mathrm{~h}$. Plates were centrifuged and $100 \mu \mathrm{l}$ of supernatant removed and counted in a $\gamma$-counter. Percent cytotoxicity was determined by the following formula: (mean experimental cpm) - (spontaneous release $\mathrm{cpm}) /($ maximal release $\mathrm{cpm})$ - (spontaneous release $\mathrm{cpm}) \times 100$. In all experiments spontaneous ${ }^{51} \mathrm{Cr}$ release was $<10 \%$.

${ }^{125} \mathrm{I}-\mathrm{IL}$-2 chemical cross-linking. ${ }^{125} \mathrm{I}-\mathrm{IL}-2(37.1 \mu \mathrm{Ci} / \mu \mathrm{g}$; New England Nuclear) was allowed to bind to cells at a final concentration of 5 $\mathrm{nM}$ (low affinity) in the presence or absence of a 200 -fold molar excess of UPC10, anti-Tac, or unlabeled recombinant IL-2. The binding was performed at $4^{\circ} \mathrm{C}$ using $20 \times 10^{6}$ Leu $11^{+}$lymphocytes or $10 \times 10^{6}$ HUT 102B2 cells suspended in $1 \mathrm{ml}$ of RPMI 1640 supplemented with $2 \%$ FCS and $25 \mathrm{mM}$ Hepes (pH 7.4). After $2 \mathrm{~h}$ of incubation the cells were pelleted; resuspended in $1 \mathrm{ml}$ of PBS (pH 8.3) containing $1 \mathrm{mM}$ $\mathrm{MgCl}_{2}$ and $0.2 \%$ azide, and cross-linked by the addition of noncleavable cross-linker disuccinimidyl suberate $(100 \mu \mathrm{g} / \mathrm{ml}$ final concentrations; Pierce Chemical Co., Rockford, IL). The cells were incubated for $30 \mathrm{~min}$ at room temperature, washed three times with PBS, and broken by dounce homogenization. The nuclei were removed by centrifugation at $400 \mathrm{~g}$ and the membrane-enriched fraction was recovered from the supernatant by centrifugation at $100,000 \mathrm{~g}$ for $1 \mathrm{~h}$. The membranes were solubilized in SDS sample buffer, boiled for $3 \mathrm{~min}$, and analyzed by SDS-PAGE on $7.5 \%$ gels under reducing conditions.

${ }^{125}$ I-IL-2 radioreceptor binding assays. As previously described (23, 24), $2.5 \times 10^{6}$ Leu $11^{+}$cells were suspended in $100 \mu \mathrm{l}$ of binding buffer (RPMI 1640 containing $2 \%$ FCS, $0.1 \%$ sodium azide, $25 \mathrm{mM}$ Hepes, pH 7.4) and incubated with increasing concentrations of ${ }^{125} \mathrm{I}-\mathrm{IL}-2$ in the presence or absence of a 500-fold molar excess of unlabeled IL-2 and 200-fold molar excess of purified anti-Tac antibody. After a 2-h incubation at $4^{\circ} \mathrm{C}$, cell associated and free ${ }^{125} \mathrm{I}-\mathrm{IL}-2$ were separated by overlaying the cell suspension on $200-\mu$ l cushions of oil (84\% silicon oil; Dexter Hysol, Olean, NY, and 16\% paraffin oil; Fisher Scientific Co., Pittsburgh, PA) and centrifugation at $12,000 \mathrm{~g}$ for $1 \mathrm{~min}$. Radioactivity present in the supernatant and excised tips were measured. The resulting data were analyzed by Scatchard plots and receptor number and apparent binding affinity calculated.

Cytoplasmic dot blots. IL-2-induced changes in specific mRNA levels in Leu $11^{+}$cells were analyzed by cytoplasmic dot hybridization as previously described (25). The nitrocellulose filters were baked and hybridized with varying cDNA probes radiolabeled with ${ }^{32} \mathrm{P}$ by the random priming method of Feinberg (26). Conditions of hybridization and washing were as previously described (27).

\section{Results}

To confirm the relative purity of the NK cell preparations, indirect immunofluorescent staining and flow microfluoro- metric analyses were performed. As shown in Fig. $1 A,>90 \%$ of these cells specifically reacted with the Leu 11 a monoclonal antibody, a cell surface marker for human NK cells (4). Also, these enriched NK cells for the most part lacked expression of the Tac antigen as $<4 \%$ of the cell population weakly reacted with the anti-Tac antibody (Fig. $1 B$ ).

In agreement with previous studies (6-10), IL-2 produced a dose-related enhancement of the cytotoxic activity of these purified NK cells against NK-sensitive K562 target cells (Fig. 2). Although some increase in cytolytic activity was observed after the addition of relatively low doses of IL-2 (10 pM), greater stimulation was always observed at higher concentrations of this lymphokine (10 nM). Inclusion of a 200 -fold molar excess of the anti-Tac antibody relative to the IL-2 concentration did not alter the IL-2-mediated augmentation of cytolytic activity (Fig. $3 \mathrm{~A}$ ).

In addition to enhancing cytotoxicity, IL-2 also stimulated an increase in NK cell proliferation as measured by $\left[{ }^{3} \mathrm{H}\right]-$ thymidine incorporation (Fig. $3 \mathrm{~B}$ ). However, in contrast to the inability of anti-Tac to block changes in cytolytic function, this monoclonal antibody almost completely inhibited IL-2induced changes in NK cell proliferation (Fig. $3 \mathrm{~B}$ ).

Taken together, these results suggest that the Tac antigen plays a critical role in IL-2-induced NK cell proliferation, but is not required for IL-2-induced enhancement of NK cytotoxic activity. To explore the possible existence of an IL-2 binding protein distinct from the Tac antigen, which potentially mediates IL-2-induced changes in NK cytotoxicity, ${ }^{125} \mathrm{I}$ IL-2 chemical cross-linking studies were performed. Under conditions permitting detection of both high and low affinity IL-2 receptors (5 nM final concentration of $\left.{ }^{125} \mathrm{I}-\mathrm{IL}-2\right)$ two major cross-linked bands of 68,000 D (band $A$ ) and 85,000 D (band $B$ ) were detected on HTLV-I-infected HUT 102B2 cells, a $\mathrm{T}$ cell line that displays both high and low affinity IL-2 receptors (Fig. 4, lane 4). Previous studies have demonstrated that these two protein bands correspond to ${ }^{125} \mathrm{I}-\mathrm{IL}-2$ crosslinked to the 50,000-55,000-D Tac antigen (band $A$ ) and a 70,000-75,000-D polypeptide (band $B$, p70). Also, these investigations have shown that the Tac and $\mathrm{p} 70$ proteins are able to independently bind IL-2 with low (dissociation constant of $\left[K_{d}\right]$ of 20-30 nM) or intermediate affinity $\left(K_{d}\right.$ of $\left.0.6-1.2 \mathrm{nM}\right)$, respectively. Furthermore, when associated, these proteins appear to form a membrane receptor complex that binds IL-2 with high affinity (12-16). In contrast to HUT 102B2 cells, cross-linking of ${ }^{125} \mathrm{I}-\mathrm{IL}-2$ to the NK cell population revealed only the presence of band $B$ indicating expression of the p70 protein in the absence of the Tac antigen (Fig. 4, lane 2). The
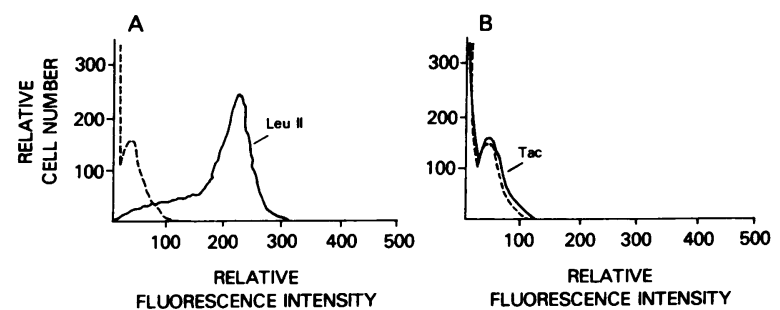

Figure 1. Fluorescent staining of purified NK cells. $1 \times 10^{6}$ negatively selected cells were immunofluorescently stained with either anti-Tac (-- $)(A)$ leu 11 la (---) $(B)$ or an isotype-matched control $(--)$ antibody and analyzed on a FACS. 


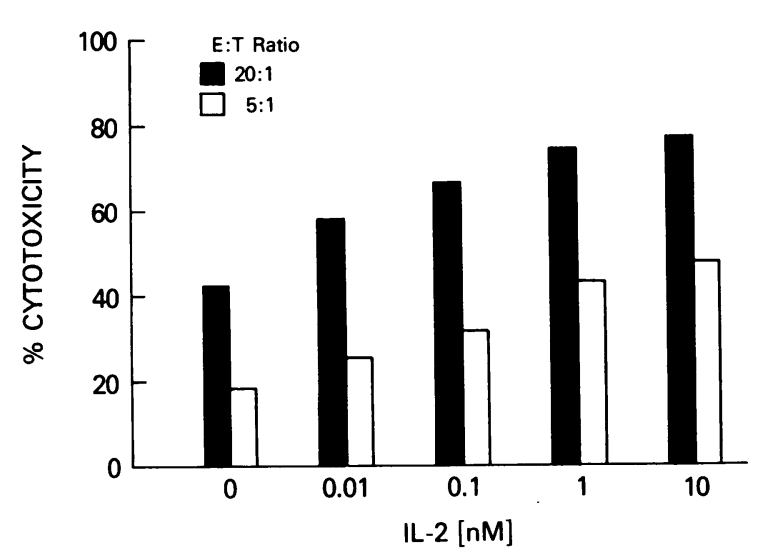

Figure 2. Increased NK cytolytic activity in response to IL-2. Leu $11^{+}$lymphocytes were purified from peripheral blood as detailed in the Methods and cultured for $18 \mathrm{~h}$ in the presence or absence of various concentrations of recombinant IL-2. The cells were washed twice and then assessed for NK cytolytic activity in a 4- $\mathrm{h}{ }^{51} \mathrm{Cr}$-release assay. $1 \mathrm{nM}$ concentration IL-2 is equivalent to $200 \mathrm{BRMP}$ reference units per $\mathrm{ml}$.
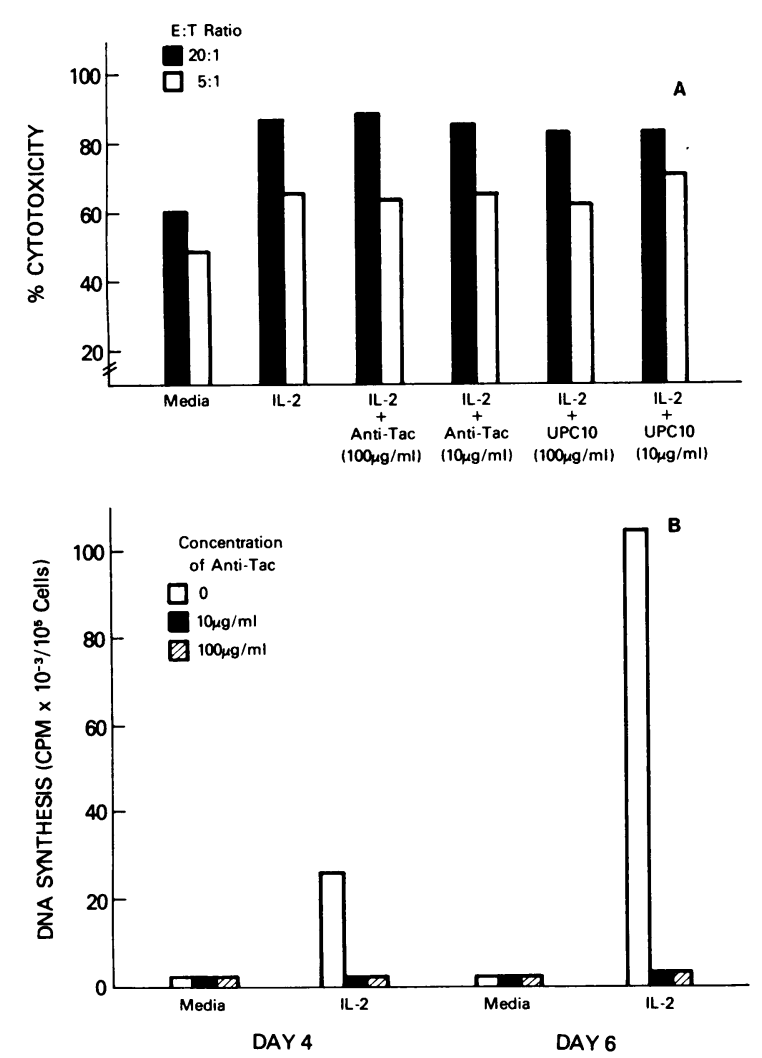

Figure 3. Anti-Tac does not inhibit IL-2-induced augmentation of NK cytolytic activity, but markedly inhibits IL-2-induced proliferation. $(A)$ Leu $11^{+}$lymphocytes were cultured for $18 \mathrm{~h}$ in the presence of IL-2 $(5 \mathrm{nM})$ and in the presence of either $100 \mu \mathrm{g} / \mathrm{ml}$ of anti-Tac antibody or $100 \mu \mathrm{g} / \mathrm{ml}$ of the UPC10 antibody. The cells were washed twice and then assessed for NK cytolytic activity in a 4-h ${ }^{51} \mathrm{Cr}$-release assay. (B) Leu $11^{+}$lymphocytes were cultured for 4 or 6 $\mathrm{d}$ in the presence or absence of the anti-Tac $(100 \mu \mathrm{g} / \mathrm{ml})$ with media alone or a $5 \mathrm{nM}$ concentration of recombinant IL-2. $\left[{ }^{3} \mathrm{H}\right]$ Thymidine incorporation was measured over the last $18 \mathrm{~h}$ of the culture period. $5 \mathrm{nM}$ concentration of IL-2 is equivalent to $1,000 \mathrm{BRMP}$ reference units per $\mathrm{ml}$.

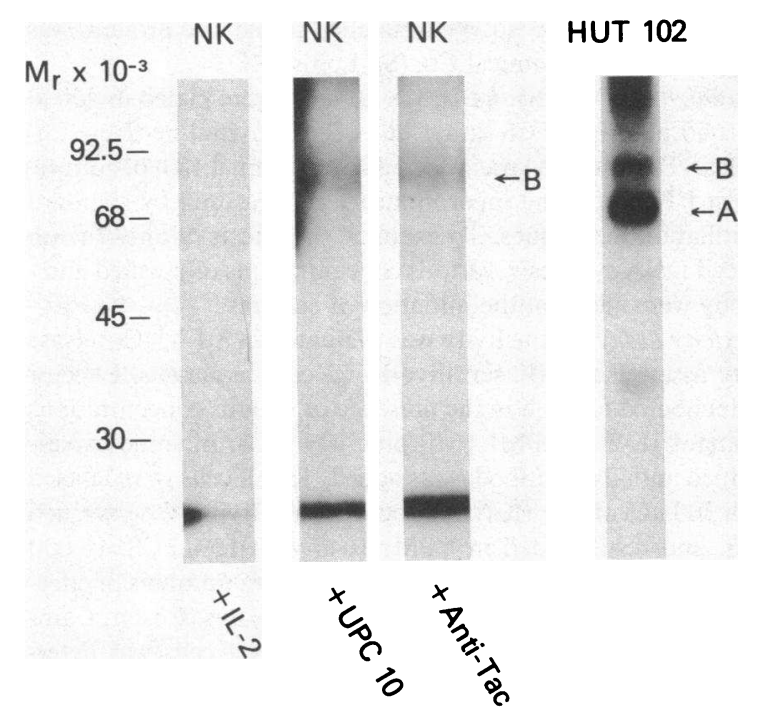

Figure 4. ${ }^{125}$ I-IL-2 cross-linking to NK cells detects an IL-2 binding protein distinct from Tac. ${ }^{125} \mathrm{I}-\mathrm{IL}-2$ was allowed to bind to purified Leu $11^{+}$cells and to Hut 102 B2 cells under low affinity $(5 \mathrm{nM})$ binding conditions. The bound ${ }^{125} \mathrm{I}-\mathrm{IL}-2$ was chemically cross-linked by the addition of dissuccinimidyl suberate as described in the Methods. Proteins were analyzed by SDS-PAGE using $7.5 \%$ gels under reducing conditions.

cross-linking to the p70 protein reflected specific binding of the radiolabeled lymphokine since the addition of a 200 -fold molar excess of unlabeled IL-2 blocked detection of this crosslinked band (Fig. 4, lane 1). In contrast, addition of similar molar excess of the anti-Tac or control UPC10 monoclonal antibodies did not alter cross-linking of ${ }^{125}$ I-IL-2 to this receptor protein (Fig. 4, lanes 2 and 3). These findings suggest the constitutive expression of the p70 IL-2 binding protein in the absence of the Tac antigen on the surface of freshly isolated and purified NK cells.

To quantitate the number and affinity of the p70 IL-2 binding sites on these NK cells, ${ }^{125} \mathrm{I}-\mathrm{IL}-2$ binding assays were performed. These studies were conducted in the presence of the anti-Tac antibody $(100 \mu \mathrm{g} / \mathrm{ml})$ to preclude the interaction of ligand with the small amounts of Tac protein occasionally present on these cells. Scatchard analysis of the specific binding data revealed $\sim 2,300$ sites per cell assuming a uniform distribution of receptors within the cell population (Fig. 5). Also, a linear Scatchard plot suggested the presence of a single-affinity class of receptors having an apparent $K_{d}$ of 200 pM. Similar binding assays performed in the absence of anti-Tac failed to reveal significant numbers of high affinity binding sites on these cells consistent with the lack of significant Tac antigen expression (data not shown).

As noted, IL-2 also stimulates a more delayed proliferative response within the NK cell population, which is blocked by the anti-Tac antibody. Thus, we next investigated the possibility that IL-2 stimulation, presumably acting through the p70 protein, modulated Tac gene expression. Cytoplasmic RNA was isolated from NK cells stimulated with $10 \mathrm{pM}$ or $5 \mathrm{nM}$ IL-2 for various times in the presence of a 200 -fold molar excess of anti-Tac, blotted andd hybridized with a ${ }^{32} \mathrm{P}$-labeled Tac cDNA fragment. As shown in Fig. $6 A$, virtually no Tac mRNA expression was detected in freshly isolated NK cells or 


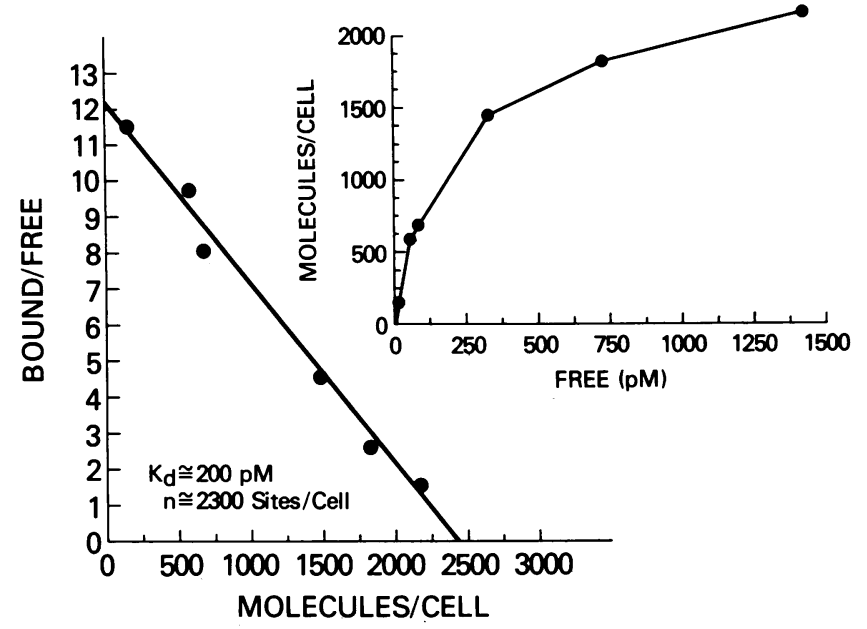

Figure 5. ${ }^{125}$ I-IL-2 radioreceptor binding assays with NK cells. IL-2 binding sites on freshly isolated Leu $11^{+}$lymphocytes were analyzed by ${ }^{125} \mathrm{I}-\mathrm{IL}-2$ binding assays as detailed in the Methods. Scatchard analysis of the binding data is presented. All results are corrected for nonspecific binding as a $\sim 35 \%$ loss of ligand binding activity incurred during the radiolabeling.

in cells activated with IL- 2 for $2 \mathrm{~h}$. In contrast, at $24 \mathrm{~h}$, a marked increase in Tac mRNA was evident. Greater amounts of Tac mRNA were always present in the cell samples stimulated with $5 \mathrm{nM}$ IL-2 compared with 10 pM IL-2, although a measurable response was consistently present at the lower IL-2 concentration. In experiments not shown, Tac mRNA was first detectable at $\sim 12 \mathrm{~h}$ after IL-2 addition. Studies of c-myb
mRNA expression revealed an early IL-2 induction of this gene occurring at $2 \mathrm{~h}$. Also, these changes were sustained for at least $24 \mathrm{~h}$. The rapid and prolonged induction of this gene raises the possibility that its gene product might play a role both in augmenting cytolytic activity and increasing cellular proliferation.

\section{Discussion}

In these studies, we have investigated the phenomenon of IL-2-induced activation of NK cells. In agreement with earlier studies, we have found that IL-2 enhancement of NK cytolytic function occurs rapidly even in the presence of the anti-Tac antibody, requires relatively high concentrations of IL-2 for optimal effects, and involves cells that largely or completely lack detectable expression of the Tac antigen. In contrast, IL-2-induced NK cell proliferation occurs with more delayed kinetics and is markedly inhibited by the anti-Tac antibody.

We have shown that freshly isolated NK cells contain on their cell surface a novel IL-2 binding protein. This IL-2 receptor is $(i)$ constitutively expressed in the absence of cellular activation signals, $(i i) \sim 70,000 \mathrm{D}$ in size $(\mathrm{p} 70)$ as assessed by the covalent cross-linking of ${ }^{125} \mathrm{I}-\mathrm{IL}-2$, (iii) unreactive with the anti-Tac antibody, and (iv) apparently identical to the recently recognized second subunit of the human high affinity IL-2 receptor (12-16). Scatchard analyses of ${ }^{125}$ I-IL-2 binding assays indicate that these highly enriched NK cells display $\sim 2,300$ p70 sites per cell that bind IL-2 with an apparent $K_{d}$ of $200 \mathrm{pM}$. The constitutive expression of these intermediate affinity p70 binding sites suggests the possibility that these
$\mathrm{Oh}$

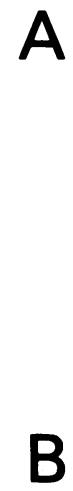

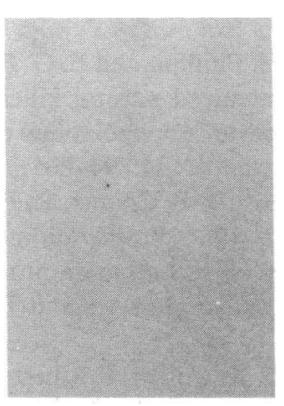
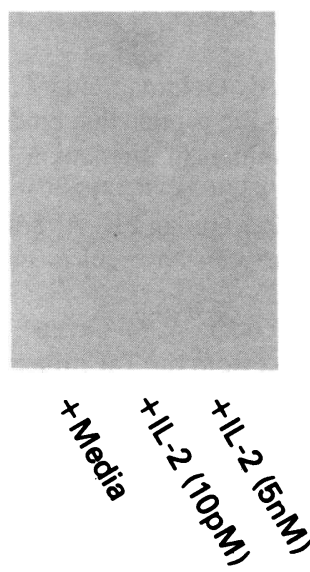

$2 \mathrm{~h}$
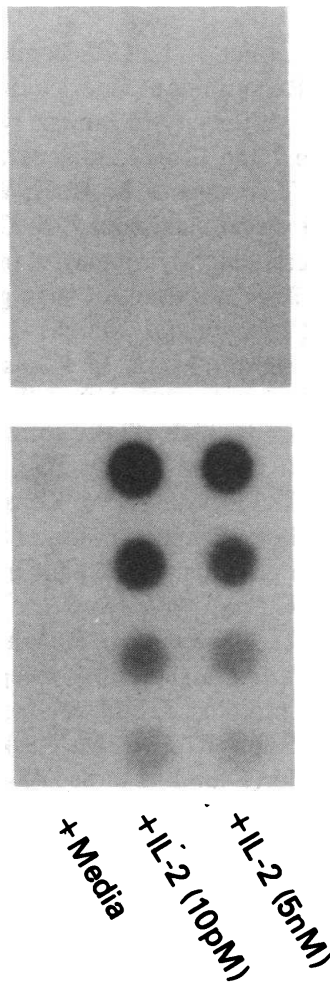

$24 \mathrm{~h}$

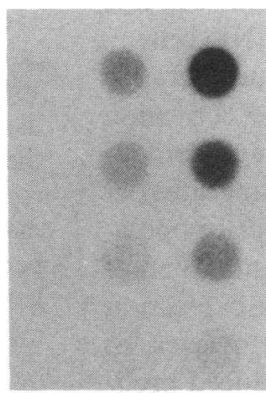

Probed with 32P-Tac cDNA

Probed with ${ }^{32} \mathrm{P}-\mathrm{cMyb}$ cDNA

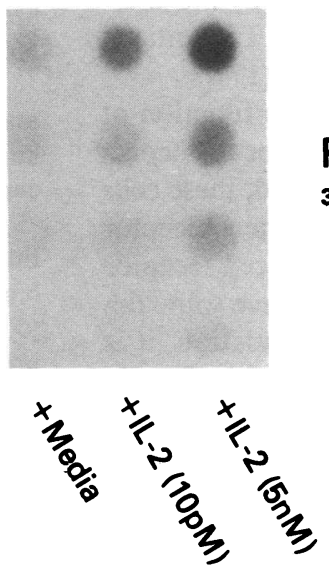

Figure 6. Induction of Tac and c-myb mRNA in IL-2-stimulated NK cells. Leu $11^{+}$cells incubated for varying time periods with IL-2 ( $5 \mathrm{nM}$ or $10 \mathrm{pM}$ ) in the presence of a 200-fold molar excess of the anti-Tac antibody. Cells were harvested at the appropriate time, and cytoplasmic dot blots performed. Nitrocellulose membranes were hybridized either with a ${ }^{32}$ P-labeled Tac cDNA fragment $(A)$ or a c-myb cDNA fragment $(B) .5 \mathrm{mM}$ concentration of IL-2 is equivalent to 1,000 BRMP reference units per ml. 
receptors may be importantly involved in transducing the requisite intracellular signals that lead to IL-2-induced enhancement of NK cytotoxicity. The inability of the anti-Tac antibody to block this action is also consistent with such a role for this receptor. Furthermore, the requirement for relatively high concentrations of IL-2 is not surprising given the intermediate affinity of these receptors for IL-2. However, formal proof that the p70 protein corresponds to the transducing structure in this response awaits the preparation of antireceptor antibodies that either block IL-2 binding or impair its capacity to function.

Our studies also demonstrate that high concentrations of IL-2 activate Tac gene expression in NK cells, probably via an interaction with the $\mathrm{p} 70$ protein. The subsequent production of Tac protein in these cells could then allow assembly of the high affinity IL-2 receptor complex that contains at least the Tac and p70 proteins. Such high affinity IL-2 receptors are clearly involved in IL-2-induced $\mathrm{T}$ cell proliferation, and, thus, by analogy, may play a similar role in IL-2-induced NK cell proliferation. The capacity of the anti-Tac antibody to inhibit IL-2-stimulated proliferation is consistent with this proposed formation of the high affinity IL-2 receptor complex.

Expression of the p70 IL-2 binding protein in the near or complete absence of the Tac antigen has also been detected on the "natural killer like" YT cell line $(14,15,28)$. YT cells contain 8,000-10,000 p70 receptors that bind IL-2 with an apparent $K_{d}$ of 810 pM. Activation of these cells with IL-2 or other stimuli, including forskolin, IL-1, or adult T cell leukemia factor $(14,15,29,30)$ also induces Tac gene expression and results in the expression of high affinity IL-2 receptors. Similarly, transfection of these cells with a plasmid containing of $5^{\prime}$ regulatory region of the Tac gene linked to the chloramphenicolacetyl transferase gene and subsequent stimulation with high concentrations of IL-2 leads to the activation of the Tac promoter (Taylor, A., and W. C. Greene, unpublished observations). Thus, IL-2 stimulation of this NK-like cell line recapitulates effects observed with freshly isolated NK cells.

High cconcentrations of IL- 2 also produce a proliferative response in resting $\mathrm{T}$ cells in the absence of other activation signals $(31,32)$. Like NK cells, recent studies have demonstrated that resting $T$ cells express $\sim 600$ p70 binding sites per cell (assuming a uniform distribution within the cell population) with an apparent $K_{\mathrm{d}}$ of $340 \mathrm{pM}$ (17). IL-2 stimulation of these cells also induces c-myb, c-myc, and Tac gene expression that is not blocked by the anti-Tac antibody. However, as found with the NK cells, the subsequent IL-2-induced proliferative response in these cells is largely inhibited by the antiTac antibody, implying the requirement for the Tac antigen and the formation of high affinity IL-2 receptors (17).

In contrast to cytotoxic $T$ cells, the cytotoxic function of NK cells does not require the recognition of major histocompatibility antigens nor is it antigen specific. Indeed, these cells often fail to express the $\mathrm{T} 3$ component of antigen receptor complex and often lack rearrangement within $\mathrm{T}$ cell receptor beta-chain gene locus (33). Whereas these cells have some degree of cytotoxic activity in the absence of stimulation, it is clear that this activity can be significantly enhanced by $\mathrm{T}$ cellderived lymphokines produced in the course of antigen or mitogen stimulation. The relatively high constitutive expression of the p70 IL-2 binding protein on these cells certainly provides a plausible mechanism to explain the capacity of IL-2 to enhance the function of these NK cells.

\section{Acknowledgments}

Ms. Whalen and Dr. Katz are supported in part by the Metropolitan Washington Chapter of the Arthritis Foundation and by U. S. Public Health Services grant AI24636.

\section{References}

1. Oldham, R. K. 1982. Natural killer cells: history and significance. J. Biol. Response Modif. 1:217-231.

2. Herberman, R. B., J. Y. Djeu, H. D. Kay, J. R. Ortaldo, C. Riccardi, G. D. Bonnard, H. T. Holden, R. Fagnani, A. Santoni, and P. Puccetti. 1979. Natural killer cells: characteristics and regulation of activity. Immunol. Rev. 44:43-70.

3. Timonen, T., J. R. Ortaldo, and R. B. Herberman. 1981. Characteristics of human large granular lymphocytes and relationship to natural killer and K cells. J. Exp. Med. 153:569-582.

4. Lanier, L. L., A. M. Le, J. H. Phillips, N. L. Warner, and G. F. Babcock. 1983. Subpopulations of human natural killer cells defined by expression of the Leu 7 (HNK-1) and Leu 11 (NKP-15) antigens. $J$. Immunol. 131:1789-1796.

5. Perussia, B., G. Trinchieri, A. Jackson, N. L. Warner, J. Faust, H. Rumpold, D. Kraft, and L. L. Lanier. 1984. The Fc receptor for IgG on human natural killer cells: phenotypic, function, and comparative studies using monoclonal antibodies. J. Immunol. 133:180-189.

6. Henney, C. S., K. Kuribayashi, D. E. Kern, and S. Gillis. 1981. Interleukin-2 augments natural killer cell activity. Nature (Lond.). 291:335-338.

7. Domzig, W., B. M. Stadler, and R. B. Herberman. 1982. Interleukin-2 dependence of human natural killer cell activity. J. Immunol. 130:1970-1973.

8. Ortaldo, J. R., A. T. Mason, J. P. Gerard, L. E. Henderson, W. Farrar, R. F. Hopkins III, R. B. Herberman, and H. Rabin. 1984. Effects of natural and recombinant IL-2 on regulation of IFN- $\gamma$ production and natural killer actiivty: lack of involvement of the Tac antigen for these immunoregulatory effects. J. Immunol. 133:779-783.

9. Trinchieri, G., M. Matsumoto-Kobayashi, S. C. Clark, J. Seehra, L. London, and B. Perussia. 1984. Response to resting human peripheral blood natural killer cells to interleukin 2. J. Exp. Med. 160:11471169.

10. Lanier, L. L., C. J. Benike, J. H. Phillips, and E. G. Engleman. 1985. Recombinant interleukin 2 enhanced natural killer cell-mediated cytotoxicity in human lymphocyte subpopulations expressing the Leu 7 and Leu 11 antigens. J. Immunol. 134:794-801.

11. Talmadge, J. E., R. H. Wiltrout, D. F. Counts, R. B. Herberman, T. McDonald, and J. R. Ortaldo. 1986. Proliferation of human peripheral blood lymphocytes induced by recombinant human interleukin 2: contribution of large granular lymphocytes and T lymphocytes. Cell Immunol. 102:261-272.

12. Sharon, M., R. D. Klausner, B. R. Cullen, R. Chizzonite, and W. J. Leonard. 1986. Novel IL-2 receptor subunit detected by crosslinking under high affinity conditions. Science (Wash. DC). 234:859863.

13. Tsudo, M., R. W. Kozak, C. K. Goldman, and T. A. Waldmann. 1986. Demonstration of a non-Tac peptide that binds interleukin 2: a potential participant in a multichain interleukin 2 receptor complex. Proc. Natl. Acad. Sci. USA. 83:9694-9698.

14. Teshigawara, K., H. Wang, K. Kato, and K. A. Smith. 1987. Interleukin 2 high-affinity receptor expression requires two distinct binding proteins. J. Exp. Med. 165:223-238.

15. Robb, R. J., C. M. Rusk, J. Yodoi, W. C. Greene. 1987. An interleukin 2 binding molecule distinct from the Tac protein: analysis of its role in formation of high affinity receptors. Proc. Natl. Acad. Sci. USA. 84:2002-2006.

16. Dukovich, M., Y. Wano, Lê thi Bich-Thuy, P. Katz, B. R. Cullen, J. H. Kehrl, and W. C. Greene. 1987. Identification of a second human interleukin- 2 binding protein and its role in the assembly of the high affinity IL-2 receptor. Nature (Lond.). 327:518-522. 
17. Lế thi Bich-Thuy, M. Dukovich, N. J. Peffer, A. S. Fauci, J. H. Kehrl, and W. C. Greene. 1987. Direct activation of human T cells by IL-2: the role of an IL-2 receptor distinct from the Tac protein. $J$. Immünol. 139:1550-1556.

18. Werner, C. H., P. T. Klouda, M. C. Correa, P. Vassali, and M. Jeannet. 1977. Isolation of B and T lymphocytes by nylon fiber columns. Tissue Antigens. 9:227-229.

19. Lê thi Bich-Thuy, and A. S. Fauci. 1986. Recombinant interleukin 2 and gamma interferon act synergistically on distinct steps of in vitro terminal human B cell maturation. J. Clin. Invest. 77:1173-1179.

20. Rosenberg, S. A., E. A. Grimm, M. McGrogan, M. Doyle, E. Kawasaki, K. Koths, and D. F. Mark. 1984. Biological activity of recombinant human interleukin-2 produced in Escherichia coli. Science (Wash. DC). 223:1412-1417.

21. Uchiyama, T., S. Broder, and T. A. Waldmann. 1980. A monoclonal antibody (anti-Tac) reactive with activated and functionally mature human T cells. J. Immunol. 126:1393-1398.

22. Leonard, W. J., J. M. Depper, T. Uchiyama, K. A. Smith, T. A. Waldmann, and W. C. Greene. 1982. A monoclonal antibody that appears to recognize the receptor for human $T$ cell growth factor: partial characterization of the receptor. Nature (Lond.). 300:267-269.

23. Robb, R. J., A. Munck, and K. A. Smith. 1981. T-cell growth factor receptors: quantification, specificity, and biological relevance. $J$. Exp. Med. 154:1455-1474.

24. Robb, R. J., W. C. Greene, and C. M. Rusk. 1984. Low and high affinity cellular receptors for interleukin 2 . Implications for the level of Tac antigens. J. Exp. Med. 160:1126-1146.

25. White, B. A., and F. C. Bancroft. 1982. Cytoplasmic dot hybridization. Simple analysis of relative mRNA levels in multiple small cell or tissue samples. J. Biol. Chem. 257:8569-8572.
26. Feinberg, A. P., B. Vogelstein. 1984. A technique for radiolabeling DNA restriction endonuclease fragments to high specific activity. Anal. Biochem. 137:266-267.

27. Krönke, M., W. J. Leonard, J. M. Depper, S. K. Arya, F. Wong-Staal, R. C. Gallo, T. A. Waldmann, and W. C. Greene. 1984. Cyclosporin A inhibits T-cell growth factor gene expression at the level of mRNA transcription. Proc. Natl. Acad. Sci. USA. 81:5214-5218.

28. Yodoi, J., K. Teshigawara, T. Nikaido, K. Fukui, T. Noma, T. Honjo, M. Takigawa, M. Sasaki, N. Minato, M. Tsudo, T. Uchiyama, and M. Maeda. 1985. TCGF (IL 2)-receptor inducing factor(s) I. Regulation of IL 2 receptor on a natural killer-like cell line (YT cells). $J$. Immunol. 134:1623-1630.

29. Shirakawa, F., Y. Tanaka, S. Eto, H. Suzuki, J. Yodoi, and U. Yamashita. 1986. Effect of interleukin 1 on the expression of interleukin 2 receptor (Tac antigen) on human natural killer cells and a natural killer-like cell line (YT cells). J. Immunol. 137:551-556.

30. Teshigawivara, K., M. Maeda, K. Nishino, T. Nikaido, T. Uchiyama, M. Tsudo, Y. Wano, and J. Yodoi. 1985. Adult T leukemia cells produce a lymphokine that augments interleukin 2 receptor expression. J. Mol. Cell. Immunol. 2:17-26.

31. Lê thi Bich-Thuy, N. J. Peffer, P. B. Svetlik, J. H. Kehrl, A. S. Fauci, and W. C. Greene. 1986. High-dose interleukin-2 (IL-2) activates the growth of unstimulated human T cells. Clin. Res. 34:491 A. (Abstr.)

32. Lê thi Bich-Thuy, H. C. Lane, and A. S. Fauci. 1986. Recombinant interleukin-2 induced polyclonal proliferation of in vitro unstimulated human peripheral blood lymphocytes. Cell. Immunol. 98:396410.

33. Lanier, L. L., S. Cwirla, N. Federspiel, and J. H. Phillips. 1986. Human natural killer cells isolated from peripheral blood do not rearrange T cell antigen receptor $\beta$ chain genes. J. Exp. Med. 163:209-214. 